INFLAMMATORY BOWEL DISEASE

\title{
Fontolizumab, a humanised anti-interferon $\gamma$ antibody, demonstrates safety and clinical activity in patients with moderate to severe Crohn's disease
}

\author{
D W Hommes, T L Mikhajlova, S Stoinov, D Štimac, B Vucelic, J Lonovics, M Zákuciová, \\ G D'Haens, G Van Assche, S Ba, S Lee, T Pearce
}

See end of article for authors' affiliations

Correspondence to:

Dr D W Hommes,

Department

Gastroenterology and

Hepatology, Academic

Medical Centre, C2-11 1

Meibergdreef 91105 AZ,

Amsterdam, the

Netherlands;

d.w.hommes@

amc.uva.nl

Revised version received 22 December 2005

Accepted for publication

24 December 2005

Published online first

28 February 2006

\begin{abstract}
Introduction: Interferon $\gamma$ is a potent proinflammatory cytokine implicated in the inflammation of Crohn's disease (CD). We evaluated the safety and efficacy of fontolizumab, a humanised anti-interferon $\gamma$ antibody, in patients with moderate to severe $C D$.

Methods: A total of 133 patients with Crohn's disease activity index (CDAl) scores between 250 and 450, inclusive, were randomised to receive placebo or fontolizumab 4 or $10 \mathrm{mg} / \mathrm{kg}$. Forty two patients received one dose and 91 patients received two doses on days 0 and 28. Investigators and patients were unaware of assignment. Study end points were safety, clinical response (decrease in CDAl of 100 points or more), and remission (CDAl $\leqslant 150$ ).

Results: There was no statistically significant difference in the primary end point of the study (clinical response) between the fontolizumab and placebo groups after a single dose at day 28 . However, patients receiving two doses of fontolizumab demonstrated doubling in response rate at day 56 compared with placebo: $32 \%(9 / 28)$ versus $69 \%(22 / 32, p=0.02)$ and $67 \%(21 / 31, p=0.03)$ for the placebo, and 4 and $10 \mathrm{mg} / \mathrm{kg}$ fontolizumab groups, respectively. Stratification according to elevated baseline $C$ reactive protein levels resulted in a decreased placebo response and pronounced differences in clinical benefit. Two grade 3 adverse events were reported and were considered to be related to CD. One death (during sleep) and one serious adverse event (an elective hospitalisation) occurred, both considered unrelated. Conclusion: Treating active CD with fontolizumab was well tolerated and resulted in increased rates of clinical response and remission compared with placebo.
\end{abstract}

p nterferon $\gamma($ IFN- $\gamma)$, a type II interferon, is one of the most potent and pleiotrophic cytokines, exhibiting a multitude of immunoregulatory functions. ${ }^{1}$ IFN- $\gamma$ can activate a wide range of immunocompetent cell types, including macrophages, endothelial cells, and lymphocytes, and is a key factor for expression of class II MHC molecules on antigen presenting cells. ${ }^{1}$ In addition, IFN- $\gamma$ decreases epithelial barrier function and promotes neutrophil migration by increased expression of chemokines and their receptors. ${ }^{2}$ In several Thl mediated models for experimental colitis, including interleukin (IL)-10, G $\alpha_{\mathrm{i} 2}$, and IL-2 deficient mice, mucosal IFN- $\gamma$ levels were increased. ${ }^{3-5}$ Also, in human Crohn's disease (CD), which has a predominantly Thl phenotype, elevated mucosal IFN- $\gamma$ levels have been observed. ${ }^{6-8}$ Therefore, strategies aimed at neutralising IFN- $\gamma$ could prove efficacious in treating CD. Anti-IFN- $\gamma$ strategies have shown benefit in another Thl autoimmune disease, rheumatoid arthritis. ${ }^{9}$

Fontolizumab (HuZAF) is the humanised form of a murine antihuman IFN $-\gamma$ antibody (Protein Design Labs, Inc., Fremont, California, USA) derived by using recombinant technology. It has shown excellent safety and tolerability in a phase I/II, double blind, placebo controlled, single and multiple dose, dose escalation study in patients with moderate to severe $\mathrm{CD} .^{10}$ Therefore, we performed a phase II, randomised, double blind, placebo controlled study of intravenous fontolizumab in active CD.

\section{MATERIALS AND METHODS}

The study complied with the International Conference of Harmonisation E6 Good Clinical Practices, United States
Food and Drug Administration regulations governing the protection of human subjects (2lCFR parts 50 and 56), Declaration of Helsinki, and any local standards of ethics. This protocol was approved by the institutional review board at each centre prior to activation, and all patients provided signed informed consent before receiving any study related procedures.

\section{Patient eligibility}

The study was conducted at 25 hospitals in Europe (Belgium, Croatia, Hungary, Russia, Slovakia, the Netherlands, and the UK). Patients were eligible for study enrolment if they were 18-70 years old and had a Crohn's disease activity index (CDAI) score of $\geqslant 250$ and $\leqslant 450$. Patients were excluded from the study if they had changed corticosteroid dose two weeks before baseline; were receiving intravenous steroids or more than $30 \mathrm{mg} /$ day of prednisone or its equivalent; had started or had a change in dose within three months of baseline of azathioprine, 6-mercaptopurine, methotrexate, or ciclosporin; had started or had a change in dose within four weeks of baseline of sulfasalazine, 5-aminosalicylic acid, or antibiotics for CD treatment; received murine, chimeric, or humanised antibody therapy within 60 days before randomisation; received investigational drugs or therapies within 30 days of randomisation; had a history of immune deficiency or autoimmune disorders other than CD; had prior or current malignancies; had serological evidence of infection with human immunodeficiency virus or hepatitis B

Abbreviations: $C D$, Crohn's disease; $C D A l$, Crohn's disease activity index; CRP, C reactive protein; DSMB, Data Safety Monitoring Board; ELISA, enzyme linked immunosorbent assay; IFN- $\gamma$, interferon $\gamma$ 


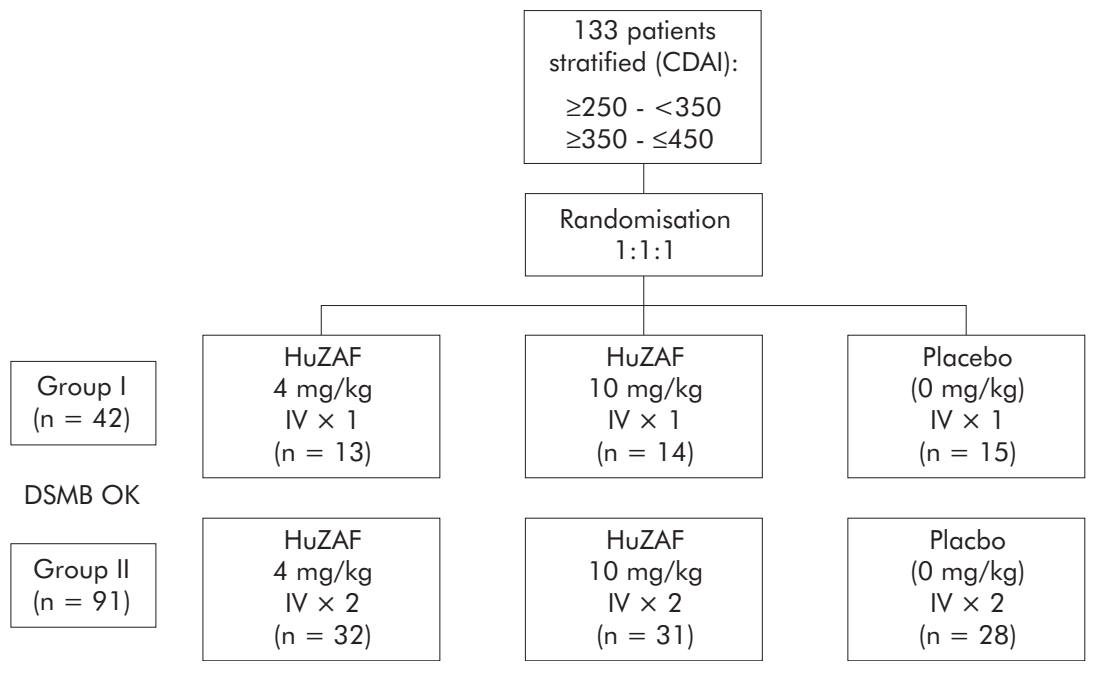

Figure 1 Study enrolment. $I V \times 1$ and IV $\times 2=$ one or two doses of study drug administered intravenously. CDAl, Crohn's disease activity index; HuZAF, fontolizumab.

or C; had evidence of Clostridium difficile, active infections requiring antibiotic therapy, or clinical history or radiographic evidence of tuberculosis; or had significant organ dysfunction or were likely to require surgery in the next six months. Patients were randomised within two CDAI strata $(\geqslant 250$ to $<350$ and $\geqslant 350$ to $\leqslant 450)$.

\section{Study design, treatment, and objectives}

This phase II, randomised, double blind (except to the site pharmacist), placebo controlled study evaluated the safety and efficacy of intravenous fontolizumab (4 or $10 \mathrm{mg} / \mathrm{kg}$ ) or placebo infused over 30 minutes in patients with moderate to severe CD. Patients who weighed $\geqslant 100 \mathrm{~kg}$ received $400 \mathrm{mg}$ if in the $4 \mathrm{mg} / \mathrm{kg}$ group or $1000 \mathrm{mg}$ if in the $10 \mathrm{mg} / \mathrm{kg}$ group.

Because multiple doses of $10 \mathrm{mg} / \mathrm{kg}$ had not previously been administered to patients, patients enrolled initially received a single intravenous dose of study treatment (group I). After reviewing safety data from the first 30 group I patients who completed day 28 assessments, a Data Safety Monitoring Board (DSMB), which was independent of the study sponsor and investigators, recommended enrolment of patients into group II. These patients received two doses of study drug, 28 days apart.
Clinical and laboratory assessments, including haematology and chemistry panels, immunogenicity, CDAI scores, adverse events, and use of concomitant medications, were determined at two week intervals up to day 56, and monthly thereafter, up to 3 months post dosing. The upper limit of normal for $\mathrm{C}$ reactive protein (CRP) for the assay used in this study was $4 \mathrm{mg} / \mathrm{l}$. The National Cancer Institute Common Toxicity Criteria, version 2.0, ${ }^{11}$ was used to rate the severity of adverse events. At six months post dosing, patients were queried about the occurrence of infectious diseases, including tuberculosis and malignancies.

Fontolizumab pharmacokinetics were assessed in a subset of patients. The sampling schedules differed slightly between groups I and II. In group I, samples were collected on day 0 at 15 minutes prior to dose and two hours post dose and on days $14,28,42,56$, and 84 . In group II, samples were collected on day 0 at 15 minutes pre-dose and two hours after the first dose; on day 14; on day 28 at 15 minutes before and two and four hours after the second dose; and on days 42, 56, 84, and 112. Serum concentrations of fontolizumab were evaluated using validated enzyme linked immunosorbent assays (ELISAs). Pharmacokinetic parameters were estimated by two compartmental analysis using WinNonlin

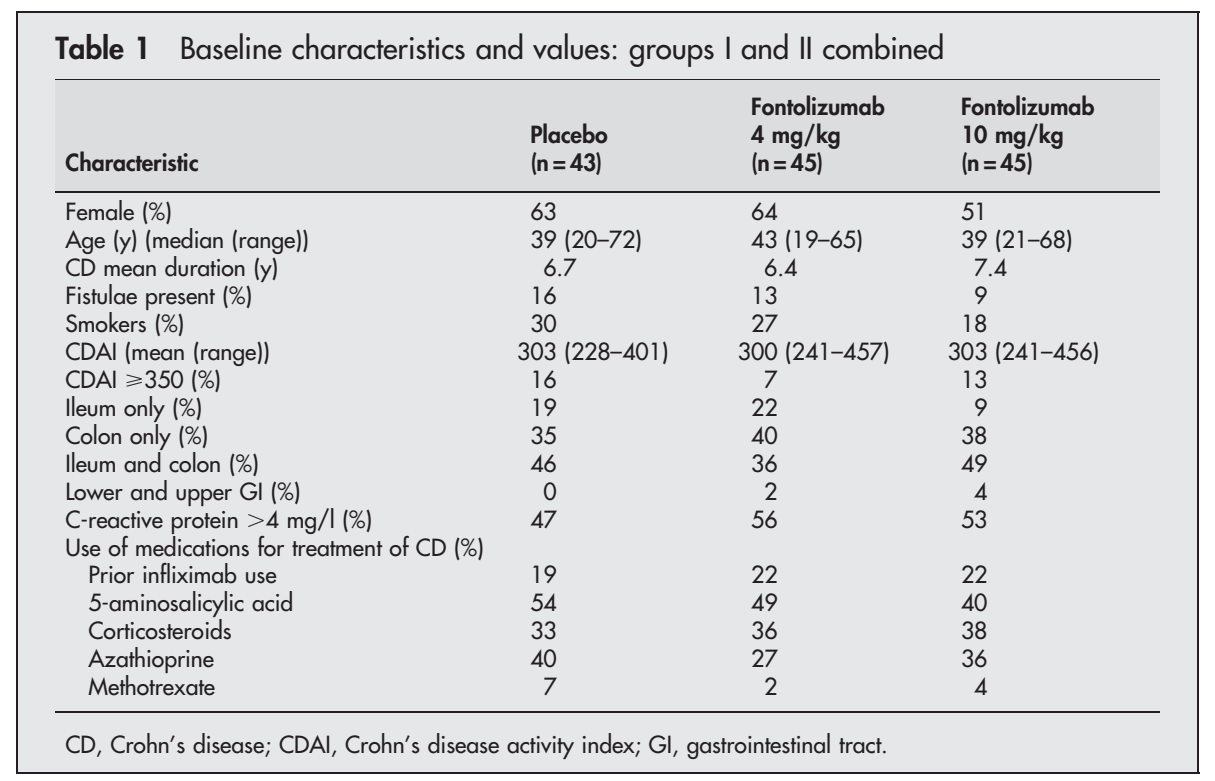


Table 2 Efficacy variables at day 28: groups I and II combined

\begin{tabular}{|c|c|c|c|}
\hline \multirow[b]{2}{*}{ Day 28 result } & \multirow[b]{2}{*}{$\begin{array}{l}\text { Placebo } \\
(n=43)\end{array}$} & \multicolumn{2}{|c|}{ Fontolizumab ( $n=45$ in each group) } \\
\hline & & $\begin{array}{l}4 \mathrm{mg} / \mathrm{kg} \\
\text { (p value*) }\end{array}$ & $\begin{array}{l}10 \mathrm{mg} / \mathrm{kg} \\
\text { (p value*) }\end{array}$ \\
\hline $\begin{array}{l}\text { Clinical response (CDAl drop of } \geqslant 100 \text { points) } \\
\text { Clinical remission (CDAl } \leqslant 150) \\
\text { CDAl change from baseline (mean) } \\
C R P \text { change from baseline (median) (mg/l) }\end{array}$ & $\begin{array}{c}14(33 \%) \\
5(12 \%) \\
-61.8 \\
0.00\end{array}$ & $\begin{array}{l}17(38 \%)(0.66) \\
14(31 \%)(0.04) \\
-99.8(0.02) \\
-0.05(0.41)\end{array}$ & $\begin{array}{l}19(44 \%)(0.38) \\
8(19 \%)(0.55) \\
-97.8(0.04) \\
-2.40(<0.01)\end{array}$ \\
\hline
\end{tabular}

(enterprise version 3.2; Pharsight Corporation, Mountain View, California, USA).

Samples for testing for the presence of anti-fontolizumab antibodies were obtained on days $0,14,28$, and 58, and three months after the last dose of study drug. On dosing days, samples were taken 15 minutes before dosing. Screening for circulating antibodies to fontolizumab was performed using a bridging ELISA. Samples that were positive in the screening assay were further analysed in a confirmatory test. Only samples giving positive or inconclusive results in the confirmatory assay were subsequently tested for the presence of neutralising antibodies.

For the screening assay, fontolizumab coated plates were used to capture anti-fontolizumab antibodies from serum, and horseradish peroxidase conjugated fontolizumab was used as the detecting reagent. An anti-idiotypic antibody against the fontolizumab murine parent antibody AF2 (antiAF2id) was used for calibration. The assay positive cut off point was established using sera from 32 untreated individuals and was set as mean optical density +2 SDs. The confirmatory assay was similarly conducted, except that excess fontolizumab was added. In order to confirm positivity, a sample had to show a reduction in signal in the presence of excess fontolizumab relative to the signal obtained without fontolizumab. The neutralisation bioassay tests the ability of anti-fontolizumab antibodies to neutralise the inhibitory function of fontolizumab on IFN- $\gamma$-induced IP-10 production in a susceptible cell line.

The primary objectives of the study were to determine the safety and response ( $\geqslant 100$ point CDAI decline compared with baseline) and remission (CDAI $\leqslant 150$ points) rates of each fontolizumab group versus placebo after a single dose at day 28. Secondary objectives included safety and response and remission rates of fontolizumab when administered as two doses, as well as the pharmacokinetics and immunogenicity results for all patients.

\section{Sample size justification}

Assuming a response rate of $70 \%$ in either of the active treatment groups and a 35\% response in the placebo group, the study was designed to have $85 \%$ power to detect a difference of 35 percentage points (at alpha $=0.05$ for the

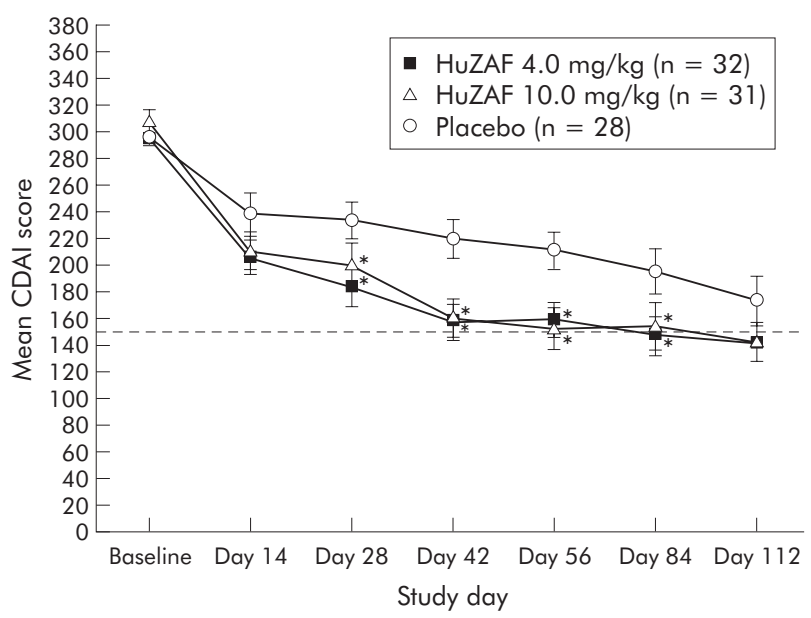

Figure 2 Mean (SEM) Crohn's disease activity index (CDAI) for patients receiving two doses of study drug. *Comparison is change from baseline value for each fontolizumab group versus placebo group. Significance is defined as $p<0.05$. HuZAF, fontolizumab.

end point), with 40 patients for each active treatment group and 40 patients for the placebo group. The total number of patients planned for the study was 120 . The study was not powered to detect statistically significant differences between fontolizumab regimens.

\section{Statistical methods}

Demographics and baseline characteristics were summarised by treatment group. Continuous variables, including baseline CDAI scores and CRP serum levels, were compared across the three treatment groups using one way analysis of variance with treatment as factor. Categorical variables were compared across the three groups using the Fisher exact test.

The proportion of patients achieving response or remission at each visit was compared between each fontolizumab group and the placebo group using the Fisher exact test. The two sample $t$ test was used for between treatment comparisons of change from baseline CDAI scores at each subsequent study visit. Change from baseline CRP value at each subsequent

Table 3 Clinical response and remission: group II

\begin{tabular}{|c|c|c|c|c|}
\hline \multirow[b]{2}{*}{ Parameter } & \multirow[b]{2}{*}{ Day } & \multirow[b]{2}{*}{ Placebo } & \multicolumn{2}{|l|}{ Fontolizumab } \\
\hline & & & $\begin{array}{l}4 \mathrm{mg} / \mathrm{kg} \\
\text { (p value*) }\end{array}$ & $\begin{array}{l}10 \mathrm{mg} / \mathrm{kg} \\
\text { (p value*) }\end{array}$ \\
\hline $\begin{array}{l}\text { Clinical response (CDAl drop of } \geqslant 100 \text { points) } \\
\text { Clinical remission (CDAl } \leqslant 150)\end{array}$ & $\begin{array}{l}42 \\
56 \\
42 \\
56\end{array}$ & $\begin{array}{l}10 / 26(39 \%) \\
9 / 26(35 \%) \\
4 / 26(15 \%) \\
7 / 26(27 \%)\end{array}$ & $\begin{array}{l}19 / 32(59 \%)(0.19) \\
22 / 32(69 \%)(0.02) \\
15 / 32(47 \%)(0.01) \\
13 / 32(41 \%)(0.41)\end{array}$ & $\begin{array}{l}20 / 31(65 \%)(0.07) \\
20 / 30(67 \%)(0.03) \\
14 / 31(45 \%)(0.02) \\
16 / 30(53 \%)(0.06)\end{array}$ \\
\hline
\end{tabular}

*Compared with placebo group.

CDAl, Crohn's disease activity index. 


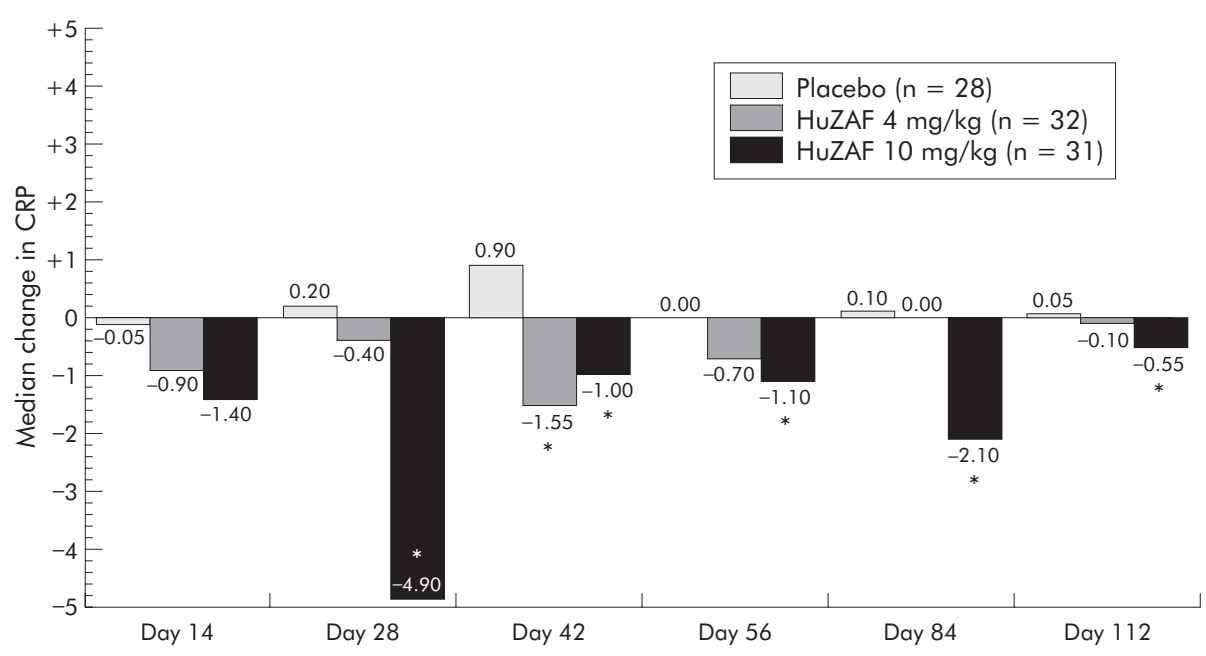

Figure 3 Median change in $\mathrm{C}$ reactive protein (CRP) in patients receiving two doses of study drug. *Each fontolizumab group compared with placebo. Significance is defined as $\mathrm{p}<0.05$. HuZAF, fontolizumab.

visit was compared between each fontolizumab group and the placebo group using the Wilcoxon rank sum test. Survival time variables were analysed using the log rank test and presented in Kaplan-Meier plots. Patients who experienced regimen failure had their last observation carried forward. Regimen failure occurs when a patient is terminated from the study due to lack of efficacy or receives an increase in dose of a concomitant medication or new medications are added as therapy for CD.

Efficacy and safety analyses were performed on all patients who received at least one dose of study medication (intent to treat population). All statistical tests were performed using two sided tests with an alpha level of 0.05 . The $p$ values presented for the secondary exploratory analyses should be interpreted as descriptive measures of the strength of evidence, independent of the scale of measurement. They are not intended to be, nor should they be interpreted as, statistical proof of any actual or assumed differences.

\section{RESULTS}

\section{Patient demographics and disease baseline characteristics}

Of the 169 patients screened, 133 (79\%) were enrolled and randomised into one of three dose groups, stratified according to CDAI score, as shown in fig 1. Approximately two thirds of patients who failed screening did not meet entry criteria (most commonly for CDAI $<250$ ); the remaining third elected not to participate. Of those enrolled, 119 completed the study, with approximately twice as many patients treated with placebo withdrawing from the study $(n=7)$, compared with either of the fontolizumab groups $(\mathrm{n}=4,4 \mathrm{mg} / \mathrm{kg} ; \mathrm{n}=3,10 \mathrm{mg} / \mathrm{kg})$. The DSMB received clinical SAS databases after 30 patients in group I completed the day 28 assessments. No major safety concerns were noted, and enrolment into group II commenced. Forty two patients received a single dose (the first 30 patients plus an additional 12 patients recruited prior to the DSMB decision) (group I), and 91 patients received two doses (group II) of study medication.

There were no statistically significant differences between the three treatment groups with regard to any demographic or baseline characteristic (table 1). Use of baseline concomitant CD therapies was similar across the three cohorts; $77 \%, 76 \%$, and $85 \%$ of patients were receiving a glucocorticoid and/or an immunosuppressant in the placebo, 4, and $10 \mathrm{mg} / \mathrm{kg}$ cohorts, respectively.

\section{Efficacy results}

There was no statistically significant difference in the primary end point of the study (clinical response) between either of the fontolizumab groups versus the placebo group after a single dose at day 28. However, 14 of 45 (31\%) patients receiving a single dose of $4 \mathrm{mg} / \mathrm{kg}$ demonstrated clinical remission at day 28 whereas only five of 43 placebo treated patients $(12 \% ; p=0.04)$ achieved this (table 2$)$.

For patients receiving two doses (group II), there was a doubling in the response rate at day 56 for each fontolizumab group compared with placebo: $35 \%(9 / 26)$ for the placebo group versus $69 \%(22 / 32, p=0.02)$ and $67 \%(20 / 30, p=0.03)$ for the $4 \mathrm{mg} / \mathrm{kg}$ and $10 \mathrm{mg} / \mathrm{kg}$ fontolizumab groups, respectively (table 3 ). There was a strong trend for increased remission, particularly at day 42 , with the placebo remission rate being $15 \%$ versus $47 \%(\mathrm{p}=0.01)$ for the $4 \mathrm{mg} / \mathrm{kg}$ and $45 \%(p=0.02)$ for the $10 \mathrm{mg} / \mathrm{kg}$ fontolizumab groups, respectively.

When change from baseline CDAI score was compared, the improvement in the fontolizumab groups was apparent as early as day 14; this was significant for the $10 \mathrm{mg} / \mathrm{kg}$ group compared with the placebo group $(\mathrm{p}=0.02)$. By day 28 there was an approximate $50 \%$ greater reduction in mean CDAI

\begin{tabular}{|c|c|c|c|}
\hline \multirow[b]{2}{*}{ Day 28 results } & \multirow[b]{2}{*}{ Placebo $(n=20)$} & \multicolumn{2}{|l|}{ Fontolizumab } \\
\hline & & $\begin{array}{l}4 \mathrm{mg} / \mathrm{kg}(\mathrm{n}=25) \\
\text { (p value*) }\end{array}$ & $\begin{array}{l}10 \mathrm{mg} / \mathrm{kg}(\mathrm{n}=24) \\
(\mathrm{p} \text { value*) }\end{array}$ \\
\hline $\begin{array}{l}\text { Clinical response (CDAl drop } \geqslant 100 \text { points) } \\
\text { Clinical remission (CDAI } \leqslant 150)\end{array}$ & $\begin{array}{l}4(20 \%) \\
0\end{array}$ & $\begin{array}{l}11(44 \%)(0.12) \\
10(40 \%)(<0.01)\end{array}$ & $\begin{array}{l}11(46 \%)(0.11) \\
4(17 \%)(0.11)\end{array}$ \\
\hline
\end{tabular}


Table 5 Adverse events with frequency of $5 \%$ or more in any treatment group

\begin{tabular}{|c|c|c|c|c|}
\hline \multirow[b]{2}{*}{ Preferred term } & \multirow[b]{2}{*}{$\begin{array}{l}\text { Placebo (\%) } \\
(n=43)\end{array}$} & \multicolumn{2}{|l|}{ Fontolizumab } & \multirow[b]{2}{*}{$\begin{array}{l}\text { Total (\%) } \\
(n=133)\end{array}$} \\
\hline & & $\begin{array}{l}4 \mathrm{mg} / \mathrm{kg}(\%) \\
(\mathrm{n}=45)\end{array}$ & $\begin{array}{l}10 \mathrm{mg} / \mathrm{kg}(\%) \\
(\mathrm{n}=45)\end{array}$ & \\
\hline Abdominal pain & $1(2.3)$ & $3(6.7)$ & $6(13.3)$ & $10(7.5)$ \\
\hline Crohn's disease & $4(9.3)$ & $4(8.9)$ & $2(4.4)$ & $10(7.5)$ \\
\hline CRP increased & $4(9.3)$ & $1(2.2)$ & $2(4.4)$ & $7(5.3)$ \\
\hline Vomiting & 0 & $4(8.9)$ & $2(4.4)$ & $6(4.5)$ \\
\hline Headache & $1(2.3)$ & $2(4.4)$ & $3(6.7)$ & $6(4.5)$ \\
\hline Nausea & $2(4.7)$ & $1(2.2)$ & $3(6.7)$ & $6(4.5)$ \\
\hline Arthralgia & 0 & 0 & $4(8.9)$ & $4(3.0)$ \\
\hline Asthenia & $1(2.3)$ & 0 & $3(6.7)$ & $4(3.0)$ \\
\hline Cough & 0 & 0 & $3(6.7)$ & $3(2.3)$ \\
\hline
\end{tabular}

from baseline in the two fontolizumab cohorts compared with the placebo group: -61.8 for placebo versus -99.8 $(p=0.02)$ and $-97.8(p=0.04)$ for the 4 and $10 \mathrm{mg} / \mathrm{kg}$ fontolizumab groups, respectively. Change from baseline CDAI score was statistically significant for patients receiving two doses of study treatment in the fontolizumab groups versus placebo patients at days 42 and 56 (fig 2, table 3). For patients in group II, time to remission demonstrated a doseresponse trend. Median time to remission was 106 days, 50 days $(\mathrm{p}=0.04)$, and 43 days $(\mathrm{p}=0.08)$ for the placebo and 4 and $10 \mathrm{mg} / \mathrm{kg}$ fontolizumab groups, respectively, in patients who received two doses. This was significant for the $4 \mathrm{mg} / \mathrm{kg}$ group only.

When median change from baseline CRP values was compared, values were significantly improved (decreased) between the $10 \mathrm{mg} / \mathrm{kg}$ and placebo groups at day 28 for all patients (fig 3, table 2). At visits after day 28, compared with placebo patients, improved CRP values were significant for group II patients in the $4 \mathrm{mg} / \mathrm{kg}$ group at day $42(\mathrm{p}<0.01)$ and in the $10 \mathrm{mg} / \mathrm{kg}$ group at days $42(\mathrm{p}<0.01)$ and 56 $(\mathrm{p}=0.05)$.

Approximately half of the patients in this study were found to have an elevated baseline CRP $(>4 \mathrm{mg} / \mathrm{l})$. The response rate to placebo at day 28 in this subset of patients was decreased by $40 \%$ compared with that of the total study population (from $33 \%$ to $20 \%$ ). On the other hand, the response rate in the two fontolizumab groups for patients with elevated CRP was numerically increased compared with the total study population randomised to these doses: $44 \%$ versus $38 \%$ for the $4 \mathrm{mg} / \mathrm{kg}$ group and $46 \%$ versus $42 \%$ for the $10 \mathrm{mg} / \mathrm{kg}$ group (tables 2,4). A similar pattern was observed for remission at day 28 (table 4 ) and for group II patients at days 42 and 56 (table 3 ).

Although there was a non-significant imbalance in the proportion of smokers and patients with fistulas at baseline between the placebo and active arms, there were insufficient numbers of patients to analyse these potential covariates.

\section{Safety results}

The percentage of patients reporting adverse events was similar across the dose groups: $42 \%, 44 \%$, and $47 \%$ of patients in the placebo, $4 \mathrm{mg} / \mathrm{kg}$, and $10 \mathrm{mg} / \mathrm{kg}$ groups, respectively, reported at least one adverse event. There were no evident patterns of adverse events specifically attributable to fontolizumab, and there were few events reported with an overall frequency greater than $5 \%$ (table 5 ). There were two grade 2 infectious events in the placebo (Campylobacter and influenza) and $4 \mathrm{mg} / \mathrm{kg}$ (jaw abscess and Herpes zoster) arms and five in the $10 \mathrm{mg} / \mathrm{kg}$ groups (influenza, pharyngitis, upper respiratory tract infection, viral infection, and condyloma accuminata). Only $4.5 \%$ of patients had serious adverse events, and all involved hospitalisation for exacerbation of CD except for one patient who was hospitalised for an elective excision of condyloma accuminata mass. At six months post dosing, there were no reports of opportunistic infections or malignancies. One death of unknown cause occurred in a 65 year old male 35 days after the second dose of $4 \mathrm{mg} / \mathrm{kg}$ fontolizumab. The death, which occurred while the man slept, was considered unrelated to the study drug by the investigator (no autopsy was performed).

\section{Pharmacokinetics}

Selected centres were identified to collect samples for pharmacokinetic assessment. Eighteen patients for whom samples were collected were dosed with placebo and thus excluded from the analysis. Forty one patients had sufficient data for pharmacokinetic analysis (four from group I and 37 from group II).

Fontolizumab pharmacokinetics were characterised by biexponential decline with an initial fast distribution phase followed by a slow elimination phase. Due to the limited number of patients in group I, this discussion focuses primarily on group II. Pharmacokinetic values are presented in table 6.

The observed serum concentrations and area under the drug concentration-time curve within one dosing interval $\left(\mathrm{AUC}_{0-\tau}\right)$ at steady state appeared to be proportional to the dose. Serum drug concentrations for most of the patients were maintained above 10 and $20 \mu \mathrm{g} / \mathrm{ml}$ for the 4 and $10 \mathrm{mg} / \mathrm{kg}$ dose groups, respectively, within the dosing period.

Consistent with previous findings, fontolizumab has low clearance and a long elimination half life (table 6), low initial

\begin{tabular}{|c|c|c|c|c|c|c|c|}
\hline \multirow[b]{2}{*}{$\begin{array}{l}\text { Dose } \\
\text { (mg/kg) }\end{array}$} & \multicolumn{2}{|c|}{ First dose } & \multicolumn{2}{|c|}{ Second dose } & \multirow[b]{2}{*}{$\begin{array}{l}\text { Clearance } \\
(\mathrm{ml} / \mathrm{h} / \mathrm{kg})\end{array}$} & \multirow[b]{2}{*}{$\begin{array}{l}\text { Steady state } A U C_{0-\tau} \\
(\mathrm{h} \times \mu \mathrm{g} / \mathrm{ml})\end{array}$} & \multirow[b]{2}{*}{$\begin{array}{l}t_{1 / 2, \beta} \\
\text { (days) }\end{array}$} \\
\hline & $\begin{array}{l}C_{\max } \\
(\mu \mathrm{g} / \mathrm{ml})\end{array}$ & $\begin{array}{l}C_{\min } \\
(\mu \mathrm{g} / \mathrm{ml})\end{array}$ & $\begin{array}{l}C_{\max } \\
(\mu \mathrm{g} / \mathrm{ml})\end{array}$ & $\begin{array}{l}\mathrm{C}_{\min } \\
(\mu \mathrm{g} / \mathrm{ml})\end{array}$ & & & \\
\hline 4 & 80 & 12 & 120 & 17 & 0.16 & 27271 & 18 \\
\hline 10 & 184 & 27 & 224 & 40 & 0.18 & 61176 & 17.7 \\
\hline
\end{tabular}

$\mathrm{AUC}_{0-\tau}$, area under the drug concentration-time curve within one dosing interval; $\mathrm{C}_{\max }$, maximum drug concentration; $C_{\min }$ minimum drug concentration; $t_{1 / 2, \beta}$, elimination half-life. 
volume of distribution $\left(\mathrm{V}_{1}\right)$ (45 and $55 \mathrm{ml} / \mathrm{kg}$ for the 4 and $10 \mathrm{mg} / \mathrm{kg}$ groups, respectively), and low volume of distribution at steady state $\left(\mathrm{V}_{\mathrm{ss}}\right)(83$ and $94 \mathrm{ml} / \mathrm{kg}$ for 4 and $10 \mathrm{mg} / \mathrm{kg}$ groups, respectively). At steady state, moderate (1.5-fold) drug accumulation is expected with monthly intravenous infusions. These main pharmacokinetic parameters were constant across the two dose groups, indicating dose independent linear kinetics for fontolizumab. Variation in pharmacokinetic values between patients was less than 33\%.

\section{Immunogenicity}

Immunogenic responses were confirmed in seven of 90 patients after fontolizumab treatment. These responses were detected as early as two weeks following the first dose and did not persist over time. Of these, four (two from each group) were positive in the neutralisation assay; however, levels were of low magnitude $(<\sim 200 \mathrm{ng} / \mathrm{ml})$. Two of these subjects, one from each dose group, had received two doses of fontolizumab. None of the positive responses was associated with either infusion reactions or obvious declines in fontolizumab exposure compared with other patients in the same treatment cohort.

\section{DISCUSSION}

This study was designed to evaluate one or two doses of fontolizumab at 4 or $10 \mathrm{mg} / \mathrm{kg}$, doses expected to provide pharmacologically active concentrations based on in vitro assays. There was no significant difference in response between the three arms at day 28 , with placebo resulting in a $33 \%$ response rate. On the other hand, the fontolizumab arms produced a $50 \%$ greater reduction in mean CDAI score compared with placebo, an advantage that was statistically significant as early as day 14 in the higher dose cohort. A subgroup analysis of approximately $50 \%$ of the study patients with an elevated CRP found that $20 \%, 44 \%$, and $46 \%$ of placebo, 4 , and $10 \mathrm{mg} / \mathrm{kg}$ fontolizumab patients, respectively, responded favourably to the study treatment at day 28 . Although the difference was not statistically significant, both doses of fontolizumab were associated with a more favourable response than placebo.

Unlike infliximab, the target for fontolizumab, interferon $\gamma$ does not exist as a membrane bound protein, and there is no in vitro evidence that target binding by fontolizumab would result in acute apoptosis of mucosal lymphocytes. Its onset of action might be more gradual, with maximum benefit observed after multiple dosing. Analysis of the patients in group II who received two doses of fontolizumab lends preliminary evidence that this might indeed be the case. On day 56 , four weeks after the second dose of study drug, the response rates in the fontolizumab arms were doubled compared with placebo: $35 \%$ in the placebo versus $69 \%$ and $67 \%$ in the 4 and $10 \mathrm{mg} / \mathrm{kg}$ fontolizumab groups, respectively. This effect was enhanced for patients with an elevated baseline CRP who received two doses, where the day 56 response rate was $17 \%$ for placebo compared with $82 \%$ for the $4 \mathrm{mg} / \mathrm{kg}$ cohort $(\mathrm{p}<0.01)$ and $77 \%$ for the $10 \mathrm{mg} / \mathrm{kg}$ fontolizumab cohort $(\mathrm{p}<0.01)$.

This clear reduction in placebo response rate and a neutral to increased impact on the fontolizumab subset is consistent with a true anti-inflammatory effect of this molecule. Further corroboration of a direct anti-inflammatory effect of fontolizumab comes from analysis of median change from baseline in CRP value. There were statistically significant reductions in the $10 \mathrm{mg} / \mathrm{kg}$ cohort of patients in group II compared with the placebo group on days $28,42,56$, and 84 . It is interesting to note that the effect on CRP was greatest in the $10 \mathrm{mg} / \mathrm{kg}$ cohort whereas $4 \mathrm{mg} / \mathrm{kg}$ appeared at least as active in terms of CDAI related parameters. This discrepancy may be due to the fact that CDAI does not always correlate well with CRP.
One of the primary end points of this study was safety, especially as $10 \mathrm{mg} / \mathrm{kg}$ fontolizumab had never been administered to patients with CD. Based on animal studies and cases of humans with non-functional interferon $\gamma$ receptors, the predicted toxicities are increased susceptibility to intracellular infections with microbacteria. Patients in this study were required to have no clinical or radiographic evidence of prior tuberculosis. All three arms were similarly well tolerated. There was no evidence of infusion reactions after one or two doses, and no clinical evidence of infectious complications of interferon $\gamma$ inhibition. One patient died in his sleep 35 days after the second dose of $4 \mathrm{mg} / \mathrm{kg}$ fontolizumab. The cause of death was presumed to be unrelated to fontolizumab, but results of larger randomised studies will be required to rule out an unexpected drug related aetiology.

Long term use of other biological agents has been limited by immunogenicity. In this study, one or two doses of fontolizumab resulted in detection of neutralising antifontolizumab antibodies in only $4.4 \%$ of patients. These antibodies were of low titre, transient (appearing typically at two weeks and becoming undetectable in subsequent sampling), and with no clinical or detectable pharmacokinetic impact. If confirmed in larger studies, with longer term dosing, the low level immunogenicity of this molecule could be of significant clinical benefit for chronic or even intermittent dosing.

In vitro bioassays of fontolizumab indicate maximal activity in the concentration range $10-100 \mu \mathrm{g} / \mathrm{ml}^{12}$ Pharmacokinetic analysis from this study reveals an elimination half life of 18 days, a peak concentration of $120 \mu \mathrm{g} / \mathrm{ml}$ after two doses of $4 \mathrm{mg} / \mathrm{kg}$ fontolizumab, and a trough concentration of $17 \mu \mathrm{g} / \mathrm{ml}$ at four weeks after the second dose. The corresponding peak and tough concentrations for the $10 \mathrm{mg} / \mathrm{kg}$ dose were $224 \mu \mathrm{g} / \mathrm{ml}$ and $40 \mu \mathrm{g} / \mathrm{ml}$, respectively. As a consequence of the long elimination half life, a clinically convenient dosing interval of every four weeks was sufficient to maintain the desired drug level in both the 4 and $10 \mathrm{mg} / \mathrm{kg}$ dose groups. Both doses thus provide sustained pharmacologically active concentrations over the dosing period, consistent with the similar levels of clinical activity between doses. Given the equivalent tolerability of both doses, the $10 \mathrm{mg} / \mathrm{kg}$ dose may allow for the development of regimens with longer, more convenient, dosing intervals.

This study has described the clinical and biological activity of fontolizumab at either one or two doses of 4 or $10 \mathrm{mg} / \mathrm{kg}$. The favourable side effect profile, long half life, and low immunogenicity suggest that more sustained dosing, and more adequately powered studies, should be considered. The $10 \mathrm{mg} / \mathrm{kg}$ dose could offer the option of dosing every 68 weeks.

\section{ACKNOWLEDGEMENTS}

We thank Dr Walther Reinisch for his critical review of this manuscript.

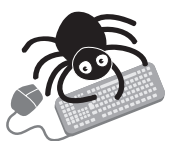

Conflict of interest: declared (the declaration can be viewed on the Gut website at http://www.gutjinl.com/ supplemental).

\footnotetext{
Authors' affiliations

D W Hommes, Department of Gastroenterology and Hepatology, Academic Medical Centre, Amsterdam, the Netherlands T L Mikhajlova, State Research Centre of Coloproctology, MZ RF, Department of Gastroenterology, Moscow, Russia

S Stoinov, MBAL Tsaritsa loanna, Department of Gastroenterology 8, Sofia, Bulgaria

D Štimac, Division of Gastroenterology, Department of Internal Medicine, Clinical Hospital Centre Rijeka, Croatia
} 
B Vucelic, Division of Gastroenterology, Department of Internal Medicine, University Hospital Rebro, Zagreb, Croatia

J Lonovics, 1 st Department of Internal Medicine, Szentgyörgyi Albert Medical University, Szeged, Hungary

M Zákuciová, I Internal Klinik, FNSP Tr SNP 1 Košice, Slovak Republic G D'Haens, Gastroenterology, Imeldaziekenhuis, Bonheiden, Belgium G V Assche, Universitaire Ziekenhuizen Gasthuisberg, Division of Gastroenterology, Leuven, Belgium

SBa, S Lee, T Pearce, Protein Design Labs, Inc., Fremont, California, USA

\section{REFERENCES}

1 Boehm U, Klamp T, Groot M, et al. Cellular responses to interferon. Annu Rev Immunol 1997; 15:749-95

2 Colgan SP, Parkos CA, Delp C, et al. Neutrophil migration across cultured intestinal epithelial monolayers is modulated by epithelial exposure to IFNgamma in a highly polarized fashion. J Cell Biol 1993;120:785-98.

3 Rennick DM, Fort MM, Davidson NJ. Studies with IL-10-/- mice: an overview. J Leukoc Biol 1997;61:389-96.

4 Hornquist CE, Lu X, Rogers-Fani PM, et al. G(alpha)i2-deficient mice with colitis exhibit a local increase in memory CD4+ T cells and proinflammatory Th1-type cytokines. J Immunol 1997;158:1068-77.

5 McDonald SA, Palmen MJ, Van Rees EP, et al. Characterization of the mucosal cell-mediated immune response in IL-2 knockout mice before and after the onset of colitis. Immunology 1997;91:73-80.

6 Breese $\mathrm{E}$, Braegger CP, Corrigan CJ, et al. Interleukin-2- and interferongamma-secreting $\mathrm{T}$ cells in normal and diseased human intestinal mucosa. Immunology 1993;78:127-31.

7 Fuss IJ, Neurath $M$, Boirivant $M$, et al. Disparate CD4+ lamina propria (LP) lymphokine secretion profiles in inflammatory bowel disease. Crohn's disease LP cells manifest increased secretion of IFN-gamma, whereas ulcerative colitis LP cells manifest increased secretion of IL-5. J Immunol 1996;157:1261-70.

8 Niessner M, Volk BA. Altered Th1/Th2 cytokine profiles in the intestinal mucosa of patients with inflammatory bowel disease as assessed by quantitative reversed transcribed polymerase chain reaction (RT-PCR). Clin Exp Immunol 1995;101:428-35.
9 Sigidin YA, Loukina GV, Skurkovich B, et al. Randomized, double-blind trial of anti-interferon-gamma antibodies in rheumatoid arthritis. Scand J Rheumatol 2001;30:203-7.

10 Rutgeerts $\mathrm{P}$, Reinisch W, Colombel J-F, et al. Preliminary results of a phase I/II study of HuZAF, an anti-IFN-gamma monoclonal antibody, in patients with moderate to severe active Crohn's disease. American Gastroenterological Association from Digestive Disease Week, May 19-22, 2002, abstract $505 .$.

11 National Cancer Institute Cancer Therapy Evaluation Program. http:// ctep.cancer.gov/reporting/ctc.html (accessed 22 May 2006).

12 Li J, Woo J, Cheung K, et al. HuZAF, a humanized anti-interferon-g monoclonal antibody, inhibits production of IFN- $\gamma$-inducible chemokines by activated human PBMC and upregulation of CXCR3 on activated T cells. Presented at American Academy of Dermatology, 61st Annual Meeting, March 2003, San Francisco, California, USA.

\section{APPENDIX}

The following investigators participated in this study: Dr Slava Djoneva, MBAL "St Ivan Rilski," Department of Internal Diseases and Clinical Pharmacology, Sofia, Bulgaria; Associate Professor Nadejda Kostova, MBAL "St Ivan Rilski," Department of Internal Diseases and Clinical Pharmacology, Sofia, Bulgaria; Associate Professor Iskren Kotsev, MBAL "St Marina," Department of Gastroenterology, Varna, Bulgaria; Dr Mario Markov, MBAL "St Anna," Department of Internal Diseases, Sofia, Bulgaria; Dr Plamen Penchev, MBAL "Tsaritsa Ioanna", Department of Gastroenterology, Sofia, Bulgaria; Dr Plamen Petrov, MBAL "St Anna," Department of Internal Diseases, Sofia, Bulgaria; Dr Megena Stamboliiska, MBAL "St Marina," Department of Gastroenterology, Varna, Bulgaria; Associate Professor Simeon Stoinov, MBAL "Tsaritsa Ioanna", Department of Gastroenterology, Sofia, Bulgaria.

\section{EDITOR'S QUIZ: GI SNAPSHOT}

\section{Answer}

From question on page 1123

The $x$ ray (fig l) shows an abnormal collection of gas in the right side of the abdomen. Linear opacities suggest intramural gas.

Computerised tomography scan (fig 2) showed caecal intramural gas and localised perforation. At laparotomy, the small bowel looked normal but there was thickening of the pericaecal tissues. A right hemicolectomy was performed. Microscopic examination of the resected bowel showed irregular spaces within the submucosa and serosa consistent

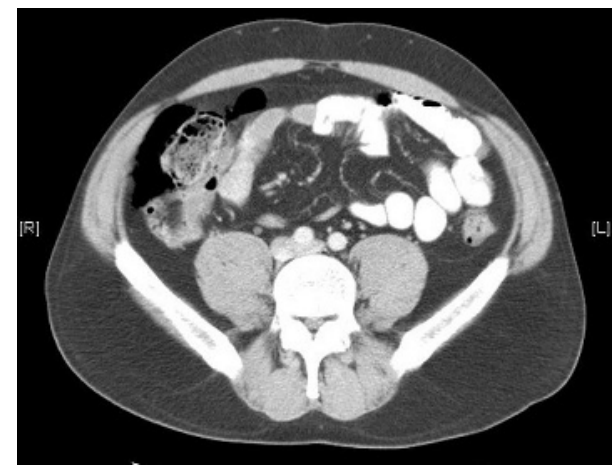

Figure 2 Computerised tomography section showing intramural gas. with pneumatosis coli, but no evidence of inflammatory bowel disease.

Pneumatosis coli is a rare condition characterised by gas within the wall of the large bowel. It can occur as a primary disorder but is more commonly the result of other pathologies (table 1). Primary pneumatosis coli usually affects the left colon. The pathophysiology is not understood but it has been suggested that either gas is forced through a mucosal breach under pressure or is produced in situ by gas forming organisms.

doi: $10.1136 /$ gut.2005.085993

Table 1 Causes of secondary pneumatosis coli

\begin{tabular}{lc}
\hline Gastrointestinal causes & Systemic causes \\
\hline Bowel inflammation/necrosis & Pulmonary disease \\
UC/Crohn's & COPD/asthma \\
Pseudomembranous colitis & Barotrauma \\
Diverticulitis & Drugs \\
Appendicitis & Steroids \\
Bowel obstruction & Immunosuppressants \\
Mucosal trauma & Chemotherapy \\
Endoscopy & Immunosuppression \\
Infection with gas forming organisms & Hepatic/renal transplantation \\
& Leukaemia \\
\hline
\end{tabular}

